\title{
Full title: Treatment of cutaneous iatrogenic Kaposi sarcoma with topical timolol
}

\section{Short running title: Treatment of KS with topical timolol}

Chap, S.*, Vu, M**, Robinson, A.J., Braue, A., Varigos, G.A., and Scardamaglia, L.

(* equal first authors)

Department of Dermatology, Royal Melbourne Hospital, Melbourne, Victoria, Australia

Address for correspondence: Dr Mi Vu, Department of Dermatology, The Royal Melbourne Hospital, Melbourne, Victoria, Australia.

Phone: 0393424531

E-mail: $\underline{\text { Hoa-Mi.Vu@mh.org.au }}$

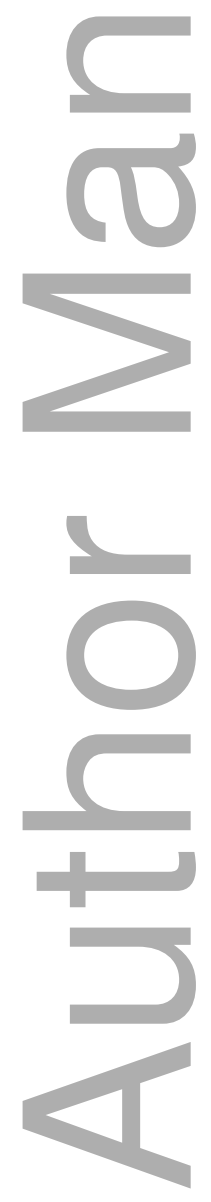

This is the author manuscript accepted for publication and has undergone full peer review but has not been through the copyediting, typesetting, pagination and proofreading process, which may lead to differences between this version and the Version of Record. Please cite this article as doi: 10.1111/ajd.12650

This article is protected by copyright. All rights reserved 
MISS SONET CHAP (Orcid ID : 0000-0003-2400-2679)

DR. MI VU (Orcid ID : 0000-0002-4093-4567)

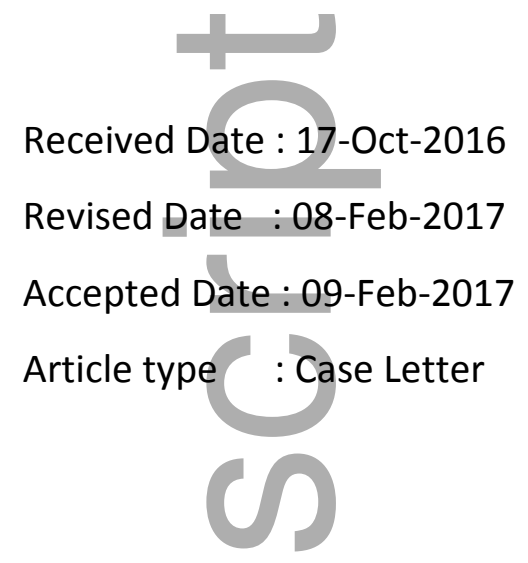

Treatment of cutaneous iatrogenic Kaposi sarcoma with topical timolol

Kaposi sarcoma (KS) is a multifocal angioproliferative neoplasm associated with human herpesvirus 8 (HHV-8). It can involve the skin, oral mucosa, lymph nodes and viscera. There are four subtypes of KS: classic (in elderly men of Mediterranean origin), iatrogenic (associated with immunosuppression), endemic (in young African men), and epidemic (HIVassociated).

Timolol is a nonselective $\beta$-adrenergic receptor antagonist formulated as an ophthalmic solution for treatment of high intraocular pressure. Within dermatology, it has been used to treat other proliferative vascular disorders such as infantile haemangiomas.

We present the case of a 61-year-old Samoan man with a 12-month history of multiple cutaneous nodules on the left lower limb. Baseline examination revealed three patchy violaceous nodules with areas of hyperkeratosis on the left medial calf, Achilles region and heel. There was circumferential subcutaneous involvement with oedema, which extended to above the knee where there were several sub-centimetre purplish nodules. The histopathological findings from the left medial calf biopsy confirmed a diagnosis of KS (with immunohistochemical staining positive for HHV-8+). Screening for HIV was negative. There was ultrasonographic evidence of bilateral inguinal lymph node involvement however a fine needle aspiration was not performed at the time.

The patient was on immunosuppression (belatacept, mycophenolate, and prednisolone) for a renal transplant two years prior, which subsequently failed secondary to antibody-mediated rejection and severe thrombotic microangiopathy. Given a diagnosis of iatrogenic KS, 
belatacept and mycophenolate were ceased to slow disease progression, but remained on prednisolone $5 \mathrm{mg}$ daily. The sub-centimetre nodules above the knee resolved with reduced immunosuppression however the lesions on the left medial calf, Achilles region and heel persisted and became more confluent and nodular. Six months after diagnosis of KS, he completed a three-month course of palliative radiotherapy of $18 \mathrm{~Gy}$ in four fractions to three sites on the left lower limb. Despite radiotherapy, the lesions progressed to become hyperkeratotic nodules, which frequently ulcerated.

Six months after completion of radiotherapy, treatment with topical timolol $0.5 \%$ gel t.d.s. was initiated and the patient reviewed every four months. To date, the patient remains on topical timolol and after 17 weeks, a dramatic improvement in the hyperkeratosis and ulceration was seen in all three sites on his left lower limb (see Fig. 1a,b). The lymphadenopathy also resolved. The patient reported no adverse effects, remained medically stable and did not receive any other treatments.

To our knowledge, two reports have been previously published on the use of topical timolol for classic KS. ${ }^{2,3}$ This is the first known case of iatrogenic KS successfully treated with topical timolol. The mechanism of action of timolol for the treatment of angioproliferative neoplasms is not well understood. Chang et al. demonstrated within infected lymphoid cells, the reactivation of HHV-8 occurred in the presence of physiological concentrations of catecholamines and that this was dependent on $\beta$-adrenergic signaling through G-protein-coupled receptor activation of the adenylate cyclase, cyclic AMP (cAMP) and phosphokinase A (PKA) pathways. ${ }^{4}$ Additionally, Chisolm et al. found strong expression of $\beta$-adrenergic receptors in up to $75 \%$ of $\mathrm{KS}^{5}{ }^{5}$ We postulate that timolol may exert its effect through the inhibition of $\beta$-adrenergic signalling by suppressing cAMP and PKA signalling pathways, and in turn suppressing the reactivation of the HHV-8, resulting in a reduction in the proliferation of $\mathrm{KS}$.

Topical timolol is a novel treatment for cutaneous KS. It is a simple, safe and effective therapy that is inexpensive, easily self-administered and associated with minimal systemic effects. Randomised, placebo-controlled trials will be required to formally establish its efficacy, long-term response and optimal length of treatment.

\section{REFERENCES}


1. Ruocco E, Ruocco V, Tornesello ML, Gambardella A, Wolf R, Buonaguro FM. Kaposi's sarcoma: Etiology and pathogenesis, inducing factors, causal associations, and treatments: Facts and controversies. Clinics in Dermatology. 2013: 413.

2. Meseguer-Yebra C, Cardeñoso-Álvarez ME, Bordel-Gómez MT, Fraile-Alonso MC, Pérez-Losada ME, Sánchez-Estella J. Successful treatment of classic Kaposi sarcoma with topical timolol: report of two cases. British Journal of Dermatology. 2015; 173: 860-2.

3. Alcantara-Reifs CM, Salido-Vallejo R, Garnacho-Saucedo GM, Velez Garcia-Nieto A. Classic Kaposi's sarcoma treated with topical 0.5\% timolol gel. Dermatologic therapy. 2016.

4. Chang M, Brown HJ, Collado-Hidalgo A, Arevalo JM, Galic Z, Symensma TL, et al. betaAdrenoreeeptors reactivate Kaposi's sarcoma-associated herpesvirus lytic replication via PKA-dependent control of viral RTA. Journal of virology. 2005; 79: 13538-47.

5. Chisholm KM, Chang KW, Truong MT, Kwok S, West RB, Heerema-McKenney AE. beta-Adrenergic receptor expression in vascular tumors. Modern pathology : an official journal of the United States and Canadian Academy of Pathology, Inc. 2012; 25: 1446-51.

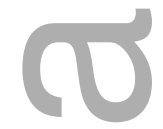

Abbreviations:

\begin{tabular}{ll}
\hline KS & Kaposi sarcoma \\
HHV-8 & Human herpesvirus 8 \\
\hline
\end{tabular}




\section{Figure legend:}

Figure 1 Clinical photography of Kaposi sarcoma on the left knee at (a) baseline and (b) 17 weeks after treatment with topical timolol.

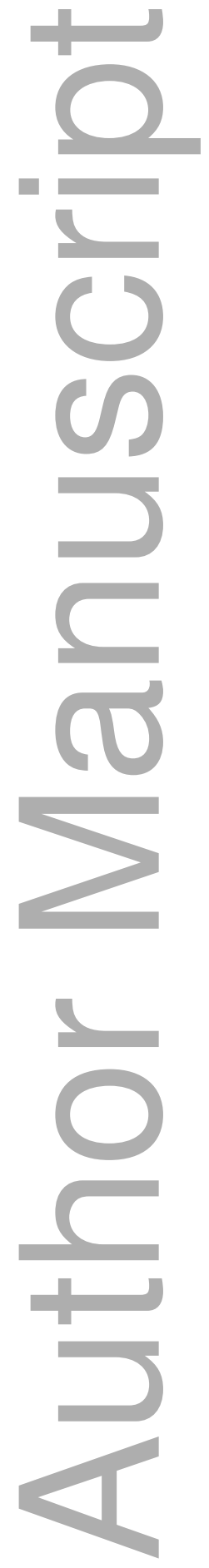




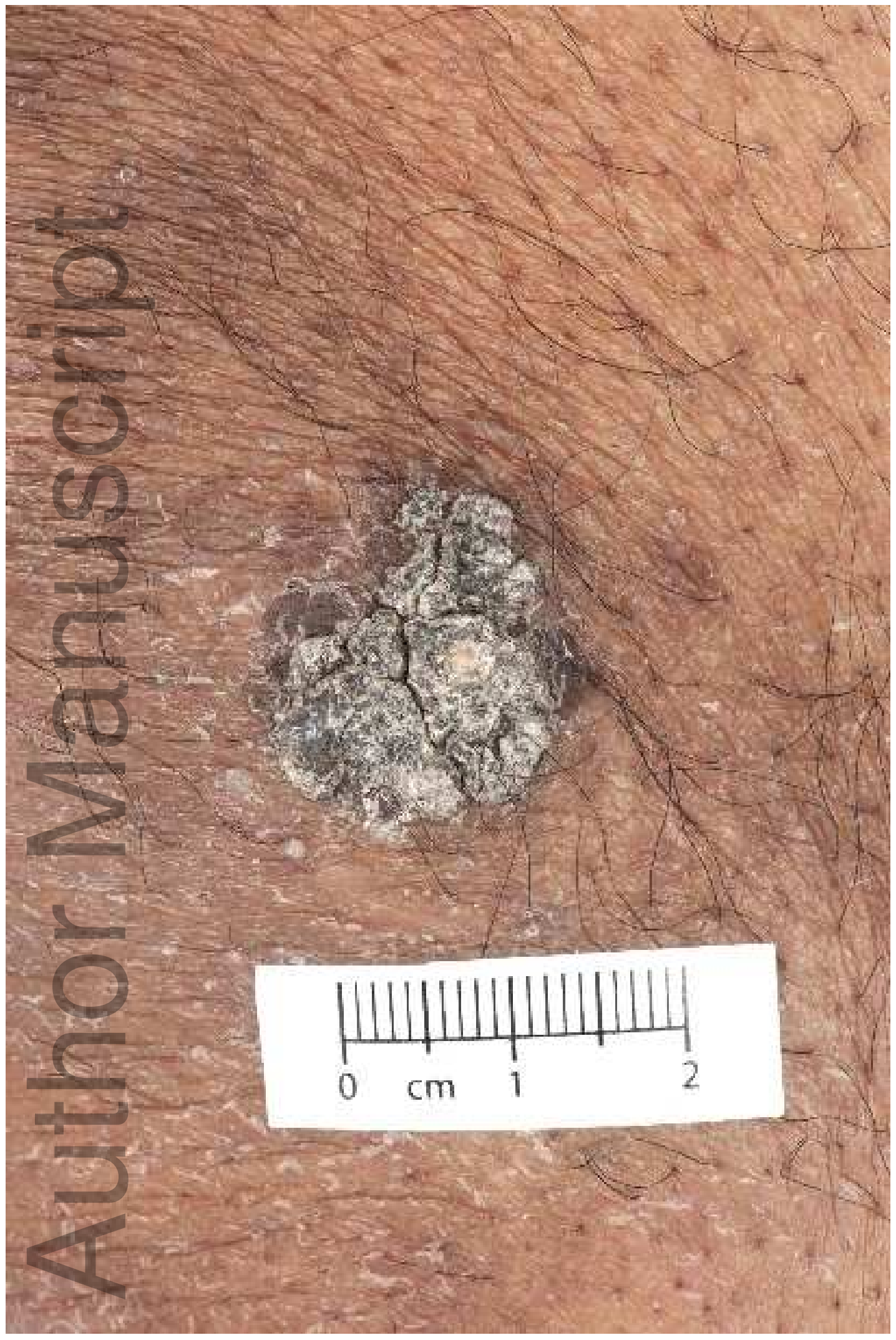

ajd_12650_f1a.tiff

This article is protected by copyright. All rights reserved 

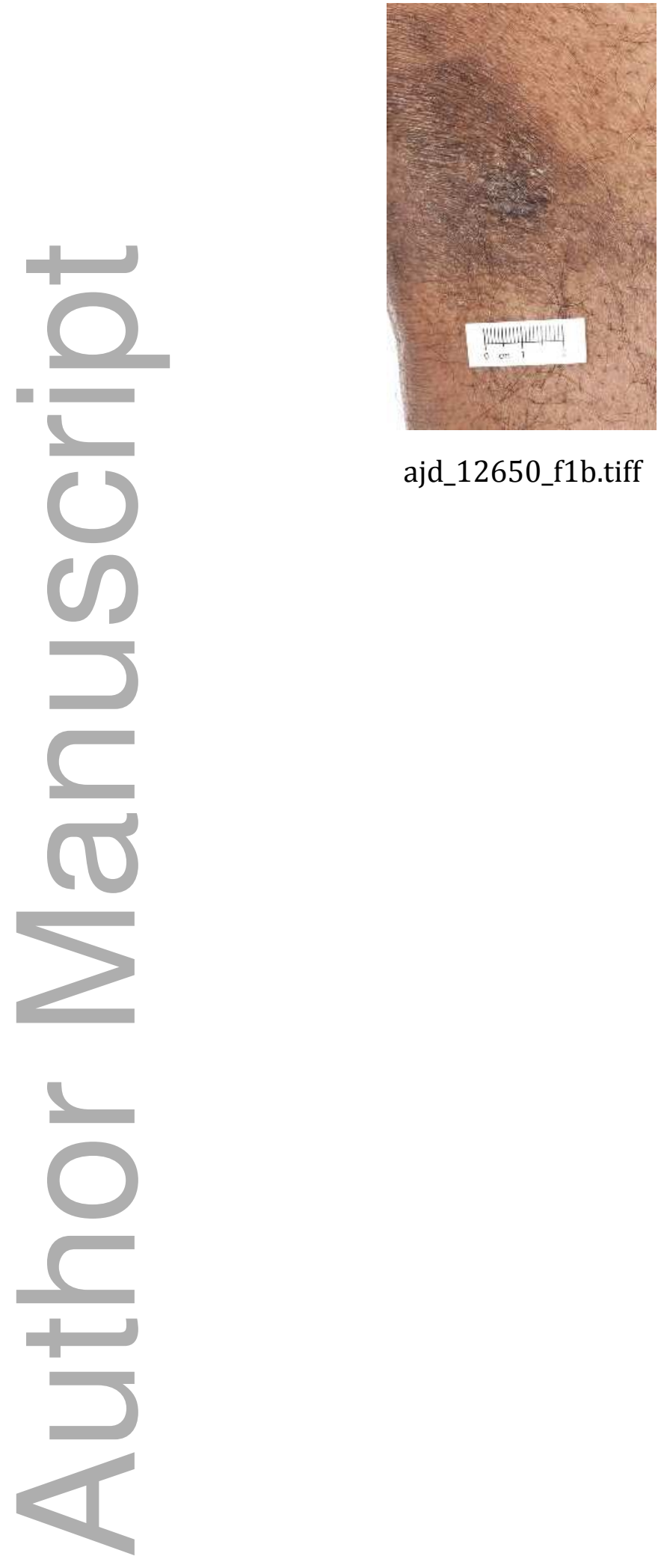

ajd_12650_f1b.tiff 


\section{University Library}

\section{- M M N E R VA A gateway to Melbourne's research publications}

Minerva Access is the Institutional Repository of The University of Melbourne

Author/s:

Chap, S;Vu, M;Robinson, AJ;Braue, A;Varigos, GA;Scardamaglia, L

Title:

Treatment of cutaneous iatrogenic Kaposi sarcoma with topical timolol

Date:

2017-08-01

Citation:

Chap, S., Vu, M., Robinson, A. J., Braue, A., Varigos, G. A. \& Scardamaglia, L. (2017).

Treatment of cutaneous iatrogenic Kaposi sarcoma with topical timolol. AUSTRALASIAN JOURNAL OF DERMATOLOGY, 58 (3), pp.242-243. https://doi.org/10.1111/ajd.12650.

Persistent Link:

http://hdl.handle.net/11343/293264 